\title{
Grazing by marine nanoflagellates on viruses and virus-sized particles: ingestion and digestion
}

\author{
Juan M. González ${ }^{1, *}$, Curtis A. Suttle ${ }^{2, * *}$ \\ ${ }^{1}$ College of Oceanography, Oregon State University, Oceanography Admin. Bldg \#104, Corvallis, Oregon 97331-5503, USA \\ ${ }^{2}$ Marine Science Institute. The University of Texas at Austin, PO Box 1267, Port Aransas, Texas 78373-1267, USA
}

\begin{abstract}
We examined grazing of marine viruses and bacteria by natural assemblages and cultures of phagotrophic nanoflagellates. Ingestion rates were determined using fluorescently labelled viruses (FLVs) and bacteria (FLB), and 50 or $500 \mathrm{~nm}$ diameter fluorescent microspheres (FMs). Calculated clearance rates of viruses by natural nanoflagellate assemblages were about $4 \%$ of those for bacteria when the bacteria and viruses were present at natural concentrations. Different viruses were ingested at different rates with the smallest virus being ingested at the slowest rate. Further, we found differences in digestion times for the same flagellates grazing on different viruses and for different flagellate assemblages grazing on the same viruses. FMs of $50 \mathrm{~nm}$ diameter were used as a control for egestion of undigested particles. As rates of digestion were greater than those for ingestion both processes would occur simultaneously; hence, our estimates of grazing rate are likely conservative. Ingestion rates were positively correlated with the concentration of $50 \mathrm{~nm}$ FMs. Discrimination against $50 \mathrm{~nm}$ FMs in favor of FLVs was also observed. Our calculations suggest that viruses may be of nutritional significance for phagotrophic flagellates. When there are $10^{6}$ bacteria $\mathrm{ml}^{-1}$ and $10^{7}$ to $10^{8}$ viruses $\mathrm{ml}^{-1}$, viruses may represent 0.2 to $9 \%$ of the carbon, 0.3 to $14 \%$ of the nitrogen and 0.6 to $28 \%$ of the phosphorus that the flagellates obtain from ingestion of bacteria. This study demonstrates that both natural assemblages and cultures of phagotrophic nanoflagellates consume and digest a variety of marine viruses, thereby deriving nutritional benefit and serving as a natural sink for marine viral particles. In addition, these results imply that some nanoflagellates are likely capable of consuming a wide spectrum of organic particles in the colloidal size range.
\end{abstract}

\section{INTRODUCTION}

Although it is well established that viruses infect marine bacteria (e.g. Spencer 1955, Hidaka 1971, Moebus 1980 ), it was only relatively recently demonstrated that the concentrations of virus-like particles in seawater are typically in excess of $10^{7} \mathrm{ml}^{-1}$, whether counted by electron or epifluorescent microscopy (Bergh et al. 1989, Proctor \& Fuhrman 1990, Suttle et al. 1990, Hara et al. 1991, Paul et al. 1991). There are also viruses which infect marine prokaryotic and eukaryotic phytoplankton (Mayer \& Taylor 1979, Suttle et al. 1990, 1991). However, our understanding of how viruses fit into aquatic foodwebs is still very incomplete. Estimates suggest that up to $16 \%$ of the bacteria in natural bacte-

\footnotetext{
- Present address: Japan Marine Science and Technology Center (JAMSTEC), 2-15 Natsushima-cho, Yokosuka 237. Japan

- Addressee for correspondence
}

rioplankton assemblages contain viral particles, which implies that a significant fraction of bacterial and cyanobacterial production may be diverted into viral production (Bergh et al. 1989, Børsheim et al. 1990, Proctor \& Fuhrman 1990, Heldal \& Bratbak 1991).

Despite the great abundance of viruses in the sea and turnover times estimated to range from hours to days (e.g. Berry \& Noton 1976, Kapuscinski \& Mitchell 1980, Heldal \& Bratbak 1991, Suttle \& Chen 1992) much remains to be learned concerning the processes responsible for the decay of infectivity and removal of viral particles from seawater. Obviously a number of mechanisms potentially contribute to the decay of viral particles and infectivity in seawater including adhesion to particulate material, bacterial exoenzymatic activity, chemical inactivation and degradation by solar radiation (e.g. Berry \& Noton 1976, Kapuscinski \& Mitchell 1980, Suttle \& Chen 1992). Another possibility is that viral particles are removed through grazing by phagotrophic flagellates. 
In this work, we report on a method for fluorescently labelling viruses so that they are suitable for use as tracers for the ingestion of viruses by phagotrophic flagellates. Using this methodology and fluorescent microspheres, we have investigated the potential of isolates and natural assemblages of nanoflagellates to ingest marine bacteriophages and virus-sized particles. We also examined digestion rates by quantifying the disappearance of ingested viruses from within flagellate food vacuoles. Our results confirm that being grazed by protists is one of the possible fates for viruses in aquatic ecosystems. In addition, our calculations indicate that viruses can contribute significantly to the nutrition of nanoflagellates. These results extend our concept of phagotrophic nanoflagellates as consumers of picoplanktonic cells, including virus-sized particles as well. This further emphasizes the key role of flagellates in aquatic microbial foodwebs and suggests that they may be even more important as remineralizers than previously conceived.

\section{MATERIALS AND METHODS}

Samples and enrichments. Seawater for grazing experiments, enrichment cultures and isolation of flagellates and viruses was collected from the pier at the Marine Science Institute of The University of Texas at Austin (Port Aransas, Texas, USA) and from a sampling site located $5 \mathrm{~km}$ due west of Yaquina Bay (Oregon, USA). The bodonid isolate (E4, ca $5 \times 8 \mu \mathrm{m}$ in size) and the enrichments of natural flagellate communities originated with seawater collected from the Oregon sampling site. Flagellate enrichments were prepared by adding $0.001 \%$ yeast extract (final concentration) to natural samples. Both monospecific cultures and natural enrichments were incubated in the dark at $15^{\circ} \mathrm{C}$ without shaking. The growth of associated bacteria resulted in a yield of approximately $10^{5}$ flagellates $\mathrm{ml}^{-1}$. With the exception of bacteriophage $\mathrm{T} 4$, the viruses used in these studies were isolated from Texas coastal waters and were pathogens of marine bacteria.

Preparation of fluorescently labelled viruses (FLVs). Viruses were fluorescently labelled by adding $0.5 \mu \mathrm{l}$ of a solution of $4 \mathrm{mg} \mathrm{ml}^{-1}$ of DTAF (5$[\{4,6$-dichlorotriazin-2-yl $\}$ amino $\}$ fluorescein) in $0.05 \mathrm{M}$ $\mathrm{Na}_{2} \mathrm{HPO}_{4}$ to $1 \mathrm{ml}$ of viral suspension (ca $10^{10}$ viruses), mixing gently and incubating overnight at $4^{\circ} \mathrm{C}$ in the dark. The DTAF solution was filtered through a $0.2 \mu \mathrm{m}$ pore-size polycarbonate filter before use. Stained viral suspensions were sonicated for $1 \mathrm{~min}$ in an ultrasonic cleaner (Branson Ultrasonic Co.), and filtered through a $0.2 \mu \mathrm{m}$ pore-size polycarbonate filter just prior to use. Sonication reduced clumping of the viruses; however, longer sonication did not improve the results and decreased viral infectivity (data not shown). Following sonication and filtration, the FLVs were counted using epifluorescence microscopy (see below) and immediately inoculated into the water samples. The infectivity of FLVs following staining and sonication was tested by plaque assays on the appropriate bacterial host.

Electron microscopy. The viruses used for the grazing studies were characterized morphologically using electron microscopy. Samples either from amplified virus stocks or from freshly filtered fluorescently labelled viral preparations were spotted onto 400 mesh carbon-coated copper grids and allowed to adsorb for $30 \mathrm{~min}$. The grids with the adsorbed viruses were then rinsed through several drops of deionized-distilled water to remove salts and stained with $1 \%$ w/v uranyl acetate and observed using either a Joel JEM-1000X or Philips 301 transmission electron microscope. Procedures are outlined further in Suttle (1993).

Ingestion rates. Aliquots (50 to $100 \mathrm{ml}$ ) of cultures or freshly collected seawater were poured into WhirlPak bags or polycarbonate flasks, which had been presoaked in $10 \%(\mathrm{v} / \mathrm{v}) \mathrm{HCl}$, and rinsed with deionized water. To allow the protists to recover from handling shock, experimental samples were incubated for 30 min prior to the beginning of each experiment. Natural flagellate communities were from the Texas sampling location and were incubated at the in situ temperature (ca $30^{\circ} \mathrm{C}$ ). Cultures and enrichments of flagellates were from Oregon and were incubated at $15^{\circ} \mathrm{C}$. Flagellate cultures were grown in $0.2 \mu \mathrm{m}$ filtered natural seawater plus $0.001 \%$ yeast extract and were used in grazing experiments during the lateexponential or stationary phases of growth.

We compared the ingestion rates of flagellates on FLVs, 50 and $500 \mathrm{~nm}$ diameter fluorescent microspheres (FMs) (Polysciences, Inc, Warrington, Pa), and fluorescently labelled bacteria (FLB) (Sherr et al 1987). All treatments were duplicated. Prior to experiments the FMs were protein-coated in $5 \mathrm{mg} \mathrm{ml}^{-1}$ albumin solution for $24 \mathrm{~h}$ (Pace \& Bailiff 1987). The FLVs and $50 \mathrm{~nm}$ FMs (virus-sized particles) were added to the samples at a final concentration of about $10^{7} \mathrm{ml}^{-1}$, whereas the FLB and 500 nm FMs (bacteria-sized particles) were added at about $10^{6} \mathrm{ml}^{-1}$. Grazing rates on different particles were determined in independent experiments. Approximately 44 to $53 \%$ of the virussized particles and 3 to $33 \%$ of the bacteria-sized particles in the natural samples were comprised of the fluorescent surrogates. The effect of particle concentration on ingestion rates of natural flagellate assemblages was corrected according to McManus \& Okubo (1991).

After the addition of the fluorescent particles, samples were taken at 5 or 15 min intervals with the more 
frequent sampling being used for the experiments at ca $30^{\circ} \mathrm{C}$. The samples were fixed by the Lugol-Formalin decoloration technique (Sherr et al. 1988) to reduce loss of material from the food vacuoles (Sherr et al. 1989). The preserved samples were stained with 4',6diamidino-2-phenylindole (DAPI) (Porter \& Feig 1980) and filtered onto $0.8 \mu \mathrm{m}$ pore-size polycarbonate filters. A minimum of 30 phagotrophic nanoflagellates were inspected for each time period to determine the average number of fluorescent particles per cell. Sometimes, it was difficult to distinguish among 2 or more FLVs or $50 \mathrm{~nm}$ FMs contained in the same food vacuole; consequently, they were counted as a single particle. This leads to conservative estimates of grazing rates. Stained viruses and $50 \mathrm{~nm}$ FMs were counted directly on glass slides with an inverted epifluorescence microscope at $1000 \times$ (Suttle et al. 1991). The FLB and $500 \mathrm{~nm}$ FMs were filtered onto $0.2 \mu \mathrm{m}$ pore-size polycarbonate filters and enumerated as above. Bacteria were counted using the acridine orange direct count method (Hobbie et al. 1977). Relative estimates of ingestion rates (fluorescent particles cell ${ }^{-1} \mathrm{~min}^{-1}$ ) and clearance rates ( $\mathrm{nl} \mathrm{cell}^{-1} \mathrm{~h}^{-1}$ ) were calculated from the uptake rates and concentrations of FLB in the experimental samples, as previously described (Fenchel 1980, Sherr et al. 1987). Flagellate grazing on different virus assemblages was compared by using the clearance rate data; ingestion rates were compared to digestion rates of the same virus assemblage in each experiment. Absolute ingestion and clearance rates were calculated for natural assemblages from estimates of relative grazing rate and concentration of virus- and bacteria-sized particles per unit volume. The rates were corrected for the increased concentration of particles resulting from the use of surrogates to measure grazing rates (see McManus \& Okubo 1991).

We estimated the amount of carbon (C), nitrogen (N) and phosphorus (P) that natural assemblages of phagotrophic nanoflagellates obtained from ingestion of viruses and bacteria using the data for absolute clearance rates. The $\mathrm{C}, \mathrm{N}$ and $\mathrm{P}$ in bacteria and viruses were assumed to be $2 \times 10^{-14} \mathrm{~g} \mathrm{C}, 0.5 \times 10^{-14}$ $\mathrm{g} \mathrm{N}$, and $0.05 \times 10^{-14} \mathrm{~g} \mathrm{P}$ per bacterium (Malone \& Ducklow 1990), and $1 \times 10^{-16} \mathrm{~g} \mathrm{C}, 0.4 \times 10^{-16} \mathrm{~g} \mathrm{~N}$, and $0.08 \times 10^{-16} \mathrm{~g}$ P per virus (Mathews et al. 1983, Børsheim et al. 1990).

Digestion rates. Digestion rate studies were carried out according to Sherr et al. (1988). Treatments and controls were duplicated. The ingestion of fluorescently labelled particles by flagellates in seawater samples or cultures was monitored. Once the average number of particles per flagellate remained constant the cultures were diluted 10 -fold with fluorescentparticle-free, $0.2 \mu \mathrm{m}$ filtered natural seawater which contained the same concentration of bacteria as the original samples. The ingestion rates in the diluted samples were determined in controls in which the concentration of fluorescent particles was the same as in the experimental samples after dilution. Decreases of fluorescent particles within the protist cells after dilution were used to calculate digestion rates. Digestion rates were calculated by regression analysis as previously described (Sherr et al. 1988). The decrease in $50 \mathrm{~nm}$ FMs in the flagellates was used as a control for the egestion of undigested virus-sized particles. Digestion times of FLV were estimated as the $x$-intercept of the digestion regression line.

We also compared flagellate ingestion and digestion rates for T4 viruses stained with either DTAF or with an FITC-labelled antibody. T4 viruses (Carolina Biological Supply) were labelled with an anti-T4 antibody made in rabbit (Antibodies Incorporated) to which an anti-rabbit FITC-antibody (Sigma Co.) from goat was conjugated. Immediately before use, labelled viruses were $0.2 \mu \mathrm{m}$ filtered to remove aggregates and possible bacterial contamination. The grazing experiments were conducted as outlined above.

Statistical analysis. Statistical analyses were carried out according to Sokal \& Rohlf (1981). A paired Student's t-test was used to compare clearance and ingestion rates of FLVs and FLBs by natural populations of phagotrophic nanoflagellates. Regression and correlation analyses were used to relate ingestion rates and densities of 50 and $500 \mathrm{~nm}$ FMs, and ingestion and digestion rates of FLVs. Differences between slopes were tested with the $F$-test for the difference between 2 regression coefficients. Differences between clearance rates of $50 \mathrm{~nm}$ FMs and FLVs, clearance rates of different viruses, and digestion times of different viruses by different flagellate assemblages were carried out using analysis of variance (ANOVA). Planned comparisons among the means were used for testing which means were significantly different from each other.

\section{RESULTS}

\section{Virus morphology}

The marine bacteriophages used in the grazing experiments were characterized using electron microscopy, and micrographs of three of these (LMG1P4, PWH3a-P1 and LB1VL-P1b) are published elsewhere (Suttle \& Chen 1992). LMG1-P4,PWH3a-P1 and LB1VM-P1a are of similar size and have head diameters of approximately 78,83 and $71 \mathrm{~nm}$, and rigid tails about 97, 104 and $86 \mathrm{~nm}$ in length, respectively. LB1VL-P1b is considerably smaller, with a head diameter of about $50 \mathrm{~nm}$ and a very short tail of approxi- 
mately $11 \mathrm{~nm}$. The LB viruses both infect a bioluminescent bacterium that has tentatively been identified as Photobacterium (Vibrio) leiognathi. The taxonomic status of the bacteria infected by the other phages is unknown.

\section{Fluorescently labelled viruses}

Several bacteriophages and an algal virus (data not shown) were successfully stained using DTAF, and even though most were $<100 \mathrm{~nm}$ in diameter they remained visible after ingestion by protists. Viruses were stained by adding 0.05 to $50 \mu \mathrm{l}$ of DTAF stock solution to a $\mathrm{ml}$ of virus suspension, but best results
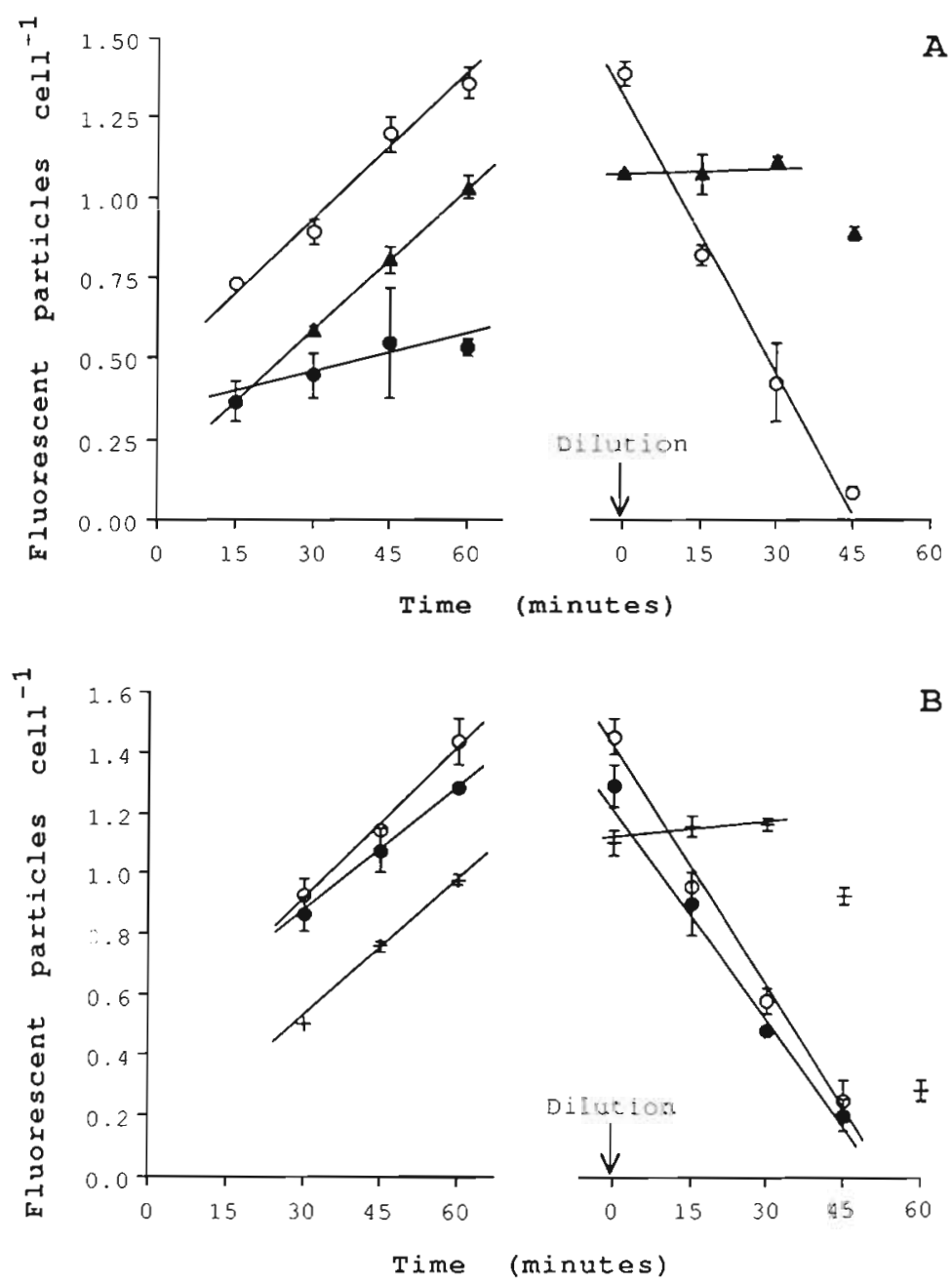

Fig. 1. Two representative ingestion (left) and digestion (right) experiments using monospecific cultures of the bodonid E4. In (A), (O) T4 FLV, (-) T4 labelled with FITC-conjugating antibody, and (4) $50 \mathrm{~nm}$ FMs were compared. In (B), FLVs made from 2 marine virus isolates, (•) PWH3a-P1 and (O) LMG1-P4, and ( + ) $50 \mathrm{~nm}$ FMs were compared. Error bars = SD of duplicate treatments were achieved when $0.5 \mu \mathrm{l}$ of the stock solution was added. Higher concentrations of stain resulted in a background which made counting difficult. No fluorescent particles were visible in the $0.2 \mu \mathrm{m}$ filtered DTAF solution that could be confused with stained viruses. The FLVs were not washed after staining as this resulted in clumping of the particles. During the short duration of our experiments the particulate material in the samples was not noticeably stained by DTAF that was introduced with the stained viruses. Staining the viruses at $4{ }^{\circ} \mathrm{C}$ was found to be optimum; at higher temperatures (i.e. 37 and $60^{\circ} \mathrm{C}$ ) viruses formed clumps which were difficult to disperse. Nonetheless, even after staining at $4{ }^{\circ} \mathrm{C}$ it was still necessary to briefly sonicate the suspension and filter it, prior to use. Infectivity of the FLVs was tested using plaque assays. Following staining the number of plaque-forming units (PFU) averaged $115 \%$ and $30 \%$ of the direct counts of PWH3a-P1 and LMG1-P4 viruses, respectively (data not shown). These results indicate that a large proportion of the FLVS are still infective following staining and, therefore, should be good tracers of natural virus communities.

Viruses tagged with FITC-labelled antibodies were also tested as a method for assessing ingestion rates of viruses by flagellates. The rate of increase in the number of antibodylabelled viruses (T4) per flagellate was much less than observed with either DTAF-stained viruses or $50 \mathrm{~nm}$ FMs. This suggests that the FITC-tagged antibodies were more easily destroyed by digestion than were viruses labelled directly with DTAF. Consequently, viruses labelled with antibodies conjugated to FITC appear to be unsuitable for estimating grazing rates by protists on viruses.

\section{Ingestion experiments}

We studied the ingestion of FLVs using natural populations, cultures and enrichments of phagotrophic nanoflagellates. Ingestion rates of FLVs and FLB by the flagellates were constant during the initial period of the incubations (Fig. 1). We also observed that the relative ingestion rates (fluorescent particles cell ${ }^{-1} \mathrm{~min}^{-1}$ ) of FLVs were greater than those for FLB, when present at concentrations of about $10^{6}$ and $10^{7} \mathrm{ml}^{-1}$, respectively (Table 1). Because of the different concentrations, however, when relative clearance rates are compared ( $\mathrm{nl}$ cell ${ }^{-1} \mathrm{~h}^{-1}$ ) 
Table 1 Comparative grazing rates of fluorescently labelled viruses (FLVs), fluorescently labelled bacteria (FLB), and $50 \mathrm{~nm}$ fluorescent microspheres (FMs) by natural populations of phagotrophic nanoflagellates in waters from the Texas coast. Individual grazing rates were determined in independent experiments. FPs: fluorescent viral-sized particles (FMs + FLVs) One SD of duplicate determinations is given in parentheses

\begin{tabular}{|c|c|c|c|c|c|c|c|}
\hline \multirow[t]{2}{*}{ Flagellates $\mathrm{ml}^{-1}$} & Type ${ }^{\text {FP }}$ & $\times 10^{7} \mathrm{ml} \cdot 1$ & \multirow[t]{2}{*}{$\begin{array}{c}\text { FLB } \\
\times 10^{\mathrm{b}} \mathrm{ml}^{-1}\end{array}$} & \multicolumn{2}{|c|}{$\begin{array}{l}\text { Ingestion rates } \\
\text { (fluorescent particles } \\
\text { cell } \mathrm{min}^{-1} \text { ) }\end{array}$} & \multicolumn{2}{|c|}{$\begin{array}{l}\text { Clearance rates } \\
\left(n l \text { cell }^{-1} \mathrm{~min}^{-1}\right)\end{array}$} \\
\hline & & & & FPs & FLB & FPS & FLB \\
\hline \multirow[t]{2}{*}{$1730(340)$} & $50 \mathrm{~nm}$ FMs & 2.3 & - & $0.022(0.002)$ & - & $0.061(0.004)$ & - \\
\hline & LB1VM-P1a & 2.1 & - & $0.030(0.005)$ & - & $0.098(0.012)$ & - \\
\hline $380(70)$ & PWH3a-P1 & 1.1 & 0.4 & $0.054(0.000)$ & $0.030(0.003)$ & $0.290(0.017)$ & $5.310(0.197)$ \\
\hline $860(140)$ & PWH3a-P1 & 1.1 & 0.9 & $0.031(0.002)$ & $0.028(0.003)$ & $0.163(0.008)$ & $2.670(0.203)$ \\
\hline $890(30)$ & PWH3a-P1 & 1.6 & 2.1 & $0.043(0.002)$ & $0.048(0.003)$ & $0.164(0.009)$ & $1.405(0.124)$ \\
\hline
\end{tabular}

those for FLBs were about 10 -fold greater than those for FLVs $(p<0.001)$. For natural assemblages of flagellates, absolute clearance rates on virus-sized particles ranged from 2.6 to $4.8 \%$ of the rates on bacteriasized particles (Table 1).

Ingestion rates by flagellates on $50 \mathrm{~nm}$ FMs were strongly dependent on concentration (Fig. 2), and there was no evidence of saturation even at $10^{8} \mathrm{FMs}$ $\mathrm{ml}^{-1}$. Thus, a one order of magnitude increase in the concentration of $50 \mathrm{~nm}$ FMs resulted in a 45 -fold increase in ingestion rates by the protists. In contrast. a similar increase in the concentration of $500 \mathrm{~nm}$ FMs resulted in only a 5 -fold increase in ingestion rate (Fig. 2). A significant difference ( $p<0.001$ ) was found between the regression coefficients relating the concentrations of 50 and $500 \mathrm{~nm}$ FMs to ingestion rates.

Absolute clearance and ingestion rates (Table 1) were calculated using the regressions in Fig. 2 to correct for the increased particle concentrations resulting from the addition of surrogates during the grazing experiments. In our experiments carried out with natural assemblages of flagellates (Table 1) comparing ingestion of viruses and bacteria, there were a total of 4.3 to $8.9 \times 10^{6}$ bacteria $\mathrm{ml}^{-1}, 3$ to $33 \%$ of which were FLB, and 2.5 to $3.0 \times 10^{7}$ viruses $\mathrm{ml}^{-1}, 44$ to $53 \%$ of which were FLVs. Those calculations resulted in estimates of flagellate clearance rates that were 3 to $31 \%$ lower for bacteria and 62 to $72 \%$ lower for virus-sized particles. Absolute ingestion and clearance rates were 3.6 - to 13.7 -fold and 20.8 - to 38.5 fold greater, respectively, on bac- teria than on viruses in natural seawater samples (Table 1).

Clearance rates of $50 \mathrm{~nm}$ FMs were significantly lower ( $p<0.001)$ than the corresponding clearance rates of FLVs by both natural populations (Table 1) and cultures (Table 2) of phagotrophic nanoflagellates. This suggests discrimination against $50 \mathrm{~nm}$ FMs in favor of FLVs. We also observed significant differences in clearance rates on different viruses. For instance, in both a bodonid culture and a flagellate enrichment, clearance rates on PWH3a-P1 and LB1VL-P1b were lower $(\mathrm{p}<0.05)$ than on LMG1-P4 (Table 2). Yet, ingestion rates were lowest on the smallest virus (LB1VL-P1b). These results indicate that grazing rates on viruses will depend greatly on both the virus and flagellate assemblages that are present.

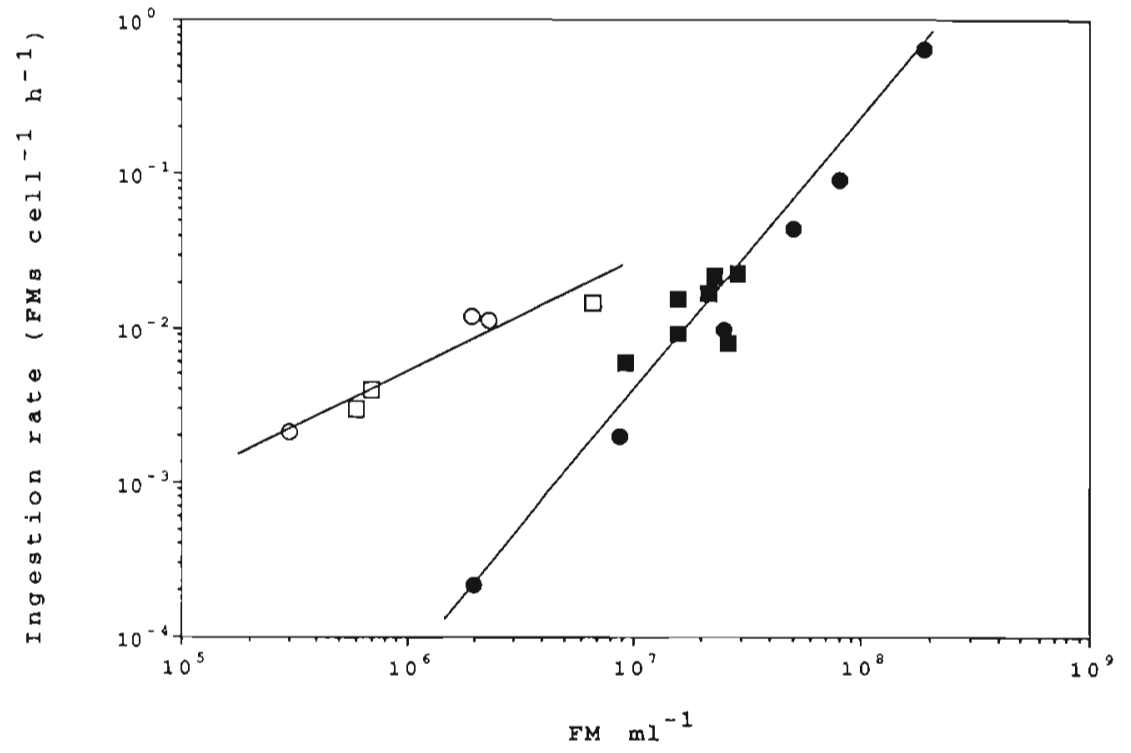

Fig. 2. Ingestion rates of $50 \mathrm{~nm}$ (filled symbols) and $500 \mathrm{~nm}$ (open symbols) diameter FMs as a function of FM concentration. Data are from experiments on natural assemblages (squares) and cultures (circles). Regression lines are: $\log y=-14.001+$ $1.656 \log x(\mathrm{r}=0.969, \mathrm{n}=14, \mathrm{p}<0.001)$, for $50 \mathrm{~nm} \mathrm{FMs}$, and $\log y=-7.560+$ $0.713 \log x(r=0.958, n=6, p<0.01)$ for $500 n m$ FMs 
Table 2. Results of some ingestion and digestion experiments comparing different FLV types and 50 nm FMs grazed upon by different flagellate assemblages. One SD in parentheses $(n=2)$

\begin{tabular}{|c|c|c|c|c|c|c|}
\hline Flagellates & $\begin{array}{l}\text { Viral-sized } \\
\text { particles }\end{array}$ & $\begin{array}{c}\text { Conc. } \\
\left(\times 10^{7} \mathrm{ml}^{-1}\right)\end{array}$ & $\begin{array}{c}\text { Ingestion rates } \\
\text { (fluorescent particles } \\
\text { cell }^{-1} \mathrm{~min}^{-1} \text { ) }\end{array}$ & $\begin{array}{c}\text { Clearance rates } \\
\left(\text { nl cell }{ }^{-1} \mathrm{~h}^{-1}\right)\end{array}$ & $\begin{array}{c}\text { Digestion rate } \\
\text { (fluorescent particles } \\
\text { cell } \mathrm{min}^{-1} \text { ) }\end{array}$ & $\begin{array}{l}\text { Digestion time } \\
\text { (min) }\end{array}$ \\
\hline Bodonid ${ }^{b}$ & $\begin{array}{l}\text { LB1VM-P1a } \\
50 \mathrm{~nm} \text { FMs }\end{array}$ & $\begin{array}{l}2.0 \\
2.8\end{array}$ & $\begin{array}{l}0.034(0.005) \\
0.023(0.004)\end{array}$ & $\begin{array}{l}0.102(0.018) \\
0.049(0.014)\end{array}$ & $0.059(0.005)^{\circ}$ & $60.0(1.4)$ \\
\hline Bodonid ${ }^{c}$ & $\begin{array}{l}\text { LMG1-P4 } \\
\text { PWH3a-P1 } \\
\text { LB1VL-P1b } \\
50 \mathrm{~nm} \text { FMs }\end{array}$ & $\begin{array}{l}1.0 \\
1.2 \\
0.9 \\
1.5\end{array}$ & $\begin{array}{l}0.017(0.002) \\
0.014(0.000) \\
0.012(0.000) \\
0.009(0.000)\end{array}$ & $\begin{array}{l}0.103(0.012) \\
0.080(0.009) \\
0.070(0.011) \\
0.036(0.000)\end{array}$ & $\begin{array}{l}0.027(0.002) \\
0.025(0.002)^{\circ} \\
0.025(0.001)^{\circ}\end{array}$ & $\begin{array}{l}52.9(0.8) \\
52.0(3.2) \\
46.1(0.6)\end{array}$ \\
\hline $\begin{array}{l}\text { Flagellate } \\
\text { enrichment }\end{array}$ & $\begin{array}{c}\text { LMG1-P4 } \\
\text { PWH3a-P1 } \\
\text { LB1VL-P1b } \\
50 \mathrm{~nm} \text { FMs }\end{array}$ & $\begin{array}{l}1.0 \\
1.2 \\
0.9 \\
1.6\end{array}$ & $\begin{array}{l}0.031(0.005) \\
0.016(0.001) \\
0.010(0.001) \\
0.009(0.000)\end{array}$ & $\begin{array}{l}0.186(0.011) \\
0.080(0.008) \\
0.066(0.009) \\
0.034(0.005)\end{array}$ & $\begin{array}{l}0.048(0.003)^{\circ} \\
0.030(0.002)^{\circ} \\
0.029(0.003)^{\circ}\end{array}$ & $\begin{array}{l}37.1(0.8) \\
52.1(1.7) \\
47.1(1.4)\end{array}$ \\
\hline Bodonid ${ }^{c}$ & $\begin{array}{c}\text { T4 } \\
50 \mathrm{~nm} \text { FMs }\end{array}$ & $\begin{array}{l}1.8 \\
2.1\end{array}$ & $\begin{array}{l}0.015(0.001) \\
0.014(0.001)\end{array}$ & $\begin{array}{l}0.052(0.009) \\
0.041(0.003)\end{array}$ & $0.029(0.002)^{\prime}$ & $46.4(2.4)$ \\
\hline \multicolumn{7}{|c|}{$\begin{array}{l}\text { aigestion rates are given as absolute values. "Significant differences at the } p<0.001 \text { level between ingestion and } \\
\text { digestion rates } \\
{ }^{b} 2.5 \text { d old culture } \\
{ }^{c} 6 \text { d old culture }\end{array}$} \\
\hline
\end{tabular}

\section{Digestion experiments}

Following the 10 -fold dilution of the experimental samples with FLV-free seawater, the number of ingested FLVs per flagellate decreased linearly with time (Fig. 1). In contrast, the concentration of ingested $50 \mathrm{~nm}$ FMs remained constant for the first $30 \mathrm{~min}$ subsequent to dilution.

Significant differences in digestion times were observed among different flagellates grazing on the same viruses and among the same flagellates grazing on different viruses (Table 2). A bodonid culture

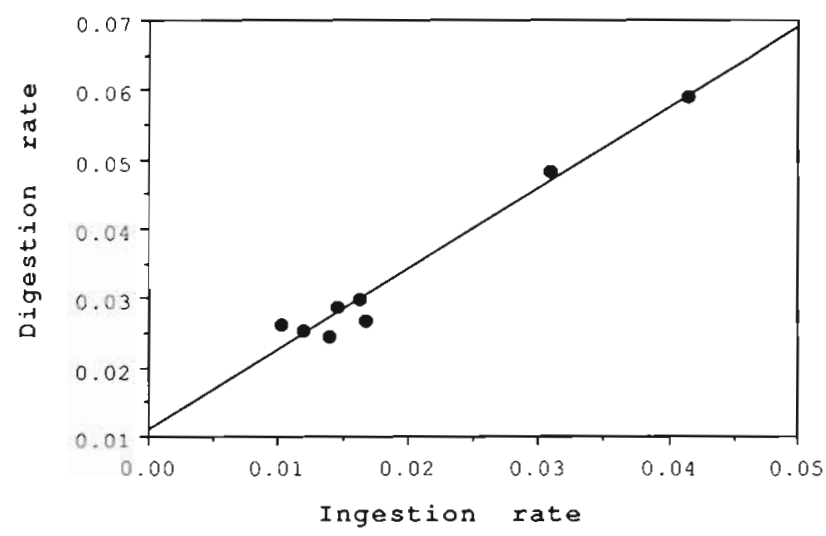

Fig. 3. Relationship between ingestion and digestion rates of FLVs by different flagellate cultures. Ingestion and digestion rates are expressed in FLVs cell ${ }^{-1} \mathrm{~min}^{-1}$. Regression line is $y=0.011+1.163 \times(r=0.985, n=8, p<0.001)$ showed similar digestion times (non-significant differences) for 2 of the assayed FLVS (53 [SD $=0.8$ ] min for LMG1-P4 and 52 [SD = 3.2] min for PWH3a-P1), but LB1VL-P1b (46 [SD =0.6] min) was digested faster $(\mathrm{p}<$ $0.01)$. However, a flagellate enrichment showed the following digestion times: $37(\mathrm{SD}=0.8), 52(\mathrm{SD}=0.7)$, and $47(\mathrm{SD}=1.4) \mathrm{min}$ for LMG1-P4,PWH3a-P1, and LB1VL-P1b, respectively, which represents significant differences $(p<0.001)$ among them. We observed that a bodonid culture and a flagellate enrichment had similar digestion times (non-significant differences) for the viral strain PWH3a-P4 and for LB1VL-P1b. Nevertheless, LMG1-P4 was digested more rapidly $(p<0.001$ ) by the flagellate enrichment than by the bodonid culture.

A comparison of ingestion and digestion rates of FLVs (Table 2) indicated that digestion rates were significantly $(\mathrm{p}<0.001)$ faster than ingestion rates, although the rates were correlated with each other $(\mathrm{r}=$ 0.985, $n=8, p<0.001$ ) (Fig. 3).

\section{DISCUSSION}

A number of important results emerged from this study. First, we were able to modify an existing technique to fluorescently label marine viruses so that they could be used as tracers of natural marine virus communities. Second, we demonstrated that viruses were ingested and digested by natural assemblages and cultures of marine nanoflagellates. Third, we showed that 
ingestion and digestion rates depended on the virus being grazed and the flagellate grazer. These results are discussed in detail below.

\section{Fluorescently labelled viruses}

In this study we prepared fluorescently labelled viruses using a stain (DTAF) which had been employed to stain bacteria (Sherr et al. 1987) and phytoplankton (Rublee \& Gallegos 1989, Sherr et al. 1991). Using this method we stained several marine bacteriophages and an algal virus, which subsequently were visible by epifluorescence microscopy. The method is probably suitable for staining a wide variety of viruses. During the staining procedure it is important to prevent the viruses from aggregating as they are difficult to disperse. We accomplished this by minimizing the handling of the viruses, staining at $4{ }^{\circ} \mathrm{C}$, sonicating for $1 \mathrm{~min}$, and then filtering the solution through $0.2 \mu \mathrm{m}$ pore size polycarbonate filters. Filtration also removed any contaminating bacteria from the FLV suspension. Using transmission electron microscopy we found that viruses prepared in this manner were present essentially as individual freeviral particles; however, we recommend that investigators check their preparation procedure by electron microscopy, as well. DTAF-stained viruses were found to be suitable for estimating protozoan grazing rates on viruses and potentially could be used for other applications where fluorescently labelled viruses would be useful as tracers. In contrast, viruses labelled by FITC, conjugated to an antibody, were found to be unsuitable for tracing virus ingestion by flagellates.

\section{Ingestion and digestion rates of viruses}

Estimates of relative clearance rates for flagellates grazing on FLB were about 10 -fold higher than those on FLVs. Similar differences in clearance rates have been found between $50 \mathrm{~nm}$ FMs and 500 nm FMs for other natural flagellate assemblages (J. M. González, C. A. Suttle, E. B. Sherr \& B. F. Sherr unpubl.). In nature, viral and bacterial abundances typically differ by a factor of about 10 (Bergh et al. 1989, Bratbak et al. 1990, Proctor \& Fuhrman 1990, Paul et al. 1991) although differences as large as 1000 -fold have been reported (Proctor \& Fuhrman 1990). Therefore, although clearance rates ( $\mathrm{nl} \mathrm{cell}^{-1} \mathrm{~h}^{-1}$ ) are higher on bacteria-sized than on virus-sized particles, ingestion rates (fluorescent particles cell ${ }^{-1} \mathrm{~min}^{-1}$ ) could be similar or even greater for virus-sized particles under certain circumstances. Nonetheless, our results conclusively demonstrate that viruses can be ingested by natural populations of phagotrophic nanoflagellates at rates that are similar to those for bacteria, when both bacteria and viruses are present at natural concentrations. The ingestion rates that we observed for PWH3aP1 (Table 1) ranged from 1.9 to 3.2 viruses cell ${ }^{-1} \mathrm{~h}^{-1}$ when the viruses were present at 1.1 to $1.6 \times 10^{7} \mathrm{ml}^{-1}$ This is very similar to reported ingestion rates of PWH3a-P1 (3.3 viruses cell ${ }^{-1} \mathrm{~h}^{-1}$ ) based on the decay of infectious viruses in the presence of heterotrophic nanoflagellates (Suttle \& Chen 1992). In addition, although flagellates are usually selective for larger particles (González et al. 1990b), there may be components of the flagellate community that are specialist grazers on viruses and virus-sized particles. For example, certain marine choanoflagellates in nature have been observed to restrict their grazing to virus-sized particles (J. M. González, C. A. Suttle, E. B. Sherr \& B. F. Sherr unpubl.).

Interestingly, flagellates ingested different viruses at different rates, implying that selective grazing was occurring although we do not know the basis of this selection. However, a natural flagellate assemblage and a bodonid culture ingested the smallest virus at the slowest rate. As viruses vary considerably in size, shape, morphology (e.g. tail structure), and surface charge there are a number of parameters that are likely important in determining ingestion rates.

Comparisons between the disappearance of FLVs and FMs from flagellate food vacuoles, subsequent to dilution with fluorescent-particle-free seawater, suggest that the viruses were digested. Dubowsky (1974) has shown that disappearance of FMs from within flagellate food vacuoles is the result of egestion. Also, observations of partially digested viruses inside the food vacuoles of flagellates (J. M. González, C. A. Suttle, E. B. Sherr \& B. F. Sherr unpubl.) provides convincing evidence that the viruses are digested although the possibility that the DTAF stain disappears more rapidly than the viruses are digested, cannot be discounted. Furthermore, egestion of intact or partially digested viruses is possible, as the process is thought to occur when some organisms graze on bacteria (Taylor \& Berger 1976, King et al. 1988, Sherr et al. 1988, González et al. 1990a).

Our results indicate that viruses were digested more rapidly than they were ingested (Table 2). Moreover, digestion times varied among different viruses grazed by the same flagellate assemblage, and among different flagellate assemblages grazing on the same viruses. Similar results have been reported for flagellates grazing on bacteria (Sherr et al. 1983, Mitchell et al. 1988, González et al. 1990a).

The ingestion rates that we report for viruses may be underestimated because of the conservative approaches that we employed in counting fluorescent 
particles within food vacuoles (see 'Materials and methods') and in estimating grazing rates (see 'Results'), and because of digestion of the viruses during the period over which ingestion rates were determined. Therefore, the importance of viruses as a nutritional source for flagellates may be greater than indicated here. For instance, PWH3a-P1, the viral strain used for comparing clearance rates on viruses and bacteria by natural assemblages of nanoflagellates, showed a lower clearance rate than other viruses tested (Table 2). Hence, clearance rates on other viruses might provide estimates much higher (up to $100 \%$ ) than those reported. Furthermore, several authors (Muller et al. 1965, Stoize et al. 1969, Wetzel \& Korn 1969, Dubowsky 1974) have shown that the digestive system in a variety of protozoa is activated upon the formation of particle-containing vacuoles. The results we obtained using viruses that were labelled with an FITC-conjugated antibody also suggest that digestion of food particles is rapidly initiated. If ingestion rates are corrected for digestion using the data in Fig. 3 then estimates of grazing rates on viruses by natural assemblages of flagellates are up to $34 \%$ higher than those reported in Table 1.

Although the flagellates were able to graze $50 \mathrm{~nm}$ FMs, the clearance rates we obtained were lower than those measured using FLVs (Table 1 \& 2). Similar results have been reported for bacterial-sized microspheres (Pace \& Bailiff 1987, Sherr et al. 1987) although some protists do not show significant differences between ingestion of FMs and FLB (Sherr et al. 1987. Sanders et al. 1989). Our results of ingestion rates on $500 \mathrm{~nm}$ FMs and FLB are in agreement with reported ingestion rates on FMs (Pace \& Bailiff 1987. Sherr et al. 1987) and FLB (Sherr et al. 1987, 1989), respectively, by heterotrophic nanoflagellates. Therefore, one must be cautious if $50 \mathrm{~nm}$ FMs are used as a surrogate for viruses in grazing experiments.

\section{Ecological implications}

We estimated the relative contributions of viruses and bacteria to the $\mathrm{C}, \mathrm{N}$ and $\mathrm{P}$ nutrition of flagellates over the range of relative densities of viruses and bacteria reported in the literature (Bergh et al. 1989, Børsheim et al. 1990, Bratbak et al. 1990, Proctor \& Fuhrman 1990, Heldal \& Bratbak 1991, Paul et al. 1991). These calculations were made using the average clearance rates for nanoflagellates grazing on bacteria or viruses (Table 1), and assuming that these rates were constant. This is a conservative assumption as the data in Fig. 2 suggest that the relative difference between the clearance rates on bacteria- and virussized particles increases as the concentrations of both increase. When the relative concentrations of viruses and bacteria differ by 5 -fold (i.e. $5 \times 10^{6}$ viruses and $10^{6}$ bacteria $\mathrm{ml}^{-1}$ ) viruses would constitute $0.1,0.2$ and $0.3 \%$ of the $\mathrm{C}, \mathrm{N}$, and $\mathrm{P}$ contributed by bacteria to the flagellate diet. When the relative concentrations differ by 50 -fold (i.e. $5 \times 10^{7}$ viruses and $10^{6}$ bacteria $\mathrm{ml}^{-1}$ ) the relative contribution by viruses would be $1.0,1.5$ and $3.1 \%$. A 500 -fold difference in the relative concentration of bacteria and viruses (i.e. $5 \times 10^{7}$ viruses and $10^{5}$ bacteria $\mathrm{ml}^{-1}$ ) would result in viruses contributing 9.6, 15.4 and $30.7 \%$, respectively, of the $\mathrm{C}, \mathrm{N}$, and $\mathrm{P}$ supplied by bacteria. These calculations indicate that viruses can be a significant source of nutrients to nanoflagellates when viruses are present at concentrations greater than 50 times that of bacteria. Similar relative concentrations of viruses and bacteria have been reported for several aquatic ecosystems (Bergh et al. 1989, Børsheim et al. 1990, Proctor \& Fuhrman 1990, Heldal \& Bratbak 1991)

Ingestion rates of flagellates have been shown to be related to the number of prey available and typically the rates saturate at high prey densities. For example, ingestion rates on bacterial-sized particles saturate at concentrations of about $10^{7}$ bacteria $\mathrm{ml}^{-1}$ (Fenchel 1982, Rassoulzadegan \& Sheldon 1986). Yet, we found no evidence of saturation at densities of virus-sized FMs up to $10^{8} \mathrm{ml}^{-1}$ (Fig. 2). Moreover, ingestion rates on virus-sized particles were strongly dependent on concentration; a 10 -fold increase in concentration (i.e. from $10^{7}$ to $10^{8} \mathrm{ml}^{-1}$ ) resulted in approximately a 45 -fold increase in ingestion rate (Fig. 2). In contrast, a 10 -fold increase in the concentration of bacterial-sized particles (i.e. from $10^{5}$ to $10^{6} \mathrm{ml}^{-1}$ ) resulted in only about a 5 -fold increase in ingestion rate. Hence, the contribution of viruses to the nutrition of nanoflagellates is proportionally much greater at high viral densities. For example, when there are about $10^{8}$ viruses and $10^{6}$ bacteria $\mathrm{ml}^{-1}$ (Bergh et al. 1989, Bratbak et al. 1990, Proctor \& Fuhrman 1990, Heldal \& Bratbak 1991), viruses could supply phagotrophic nanoflagellates with a minimum of 9,14 and $28 \%$ of the $\mathrm{C}, \mathrm{N}$ and $P$ that they receive from ingestion of bacteria.

Results from this study suggest that phagotrophy by nanoflagellates is of limited importance as a loss process for natural virioplankton communities. Our data (Table 1) would imply turnover times of virus communities on the order of years if grazing by nanoflagellates was the only loss process responsible for the removal of viruses.

Grazing by nanoflagellates is another mechanism besides infection which incorporates viruses into the $\mathrm{C}$, $\mathrm{N}$, and $\mathrm{P}$ cycles of aquatic systems. Our results, coupled with observations that nanoflagellates can ingest high-molecular-weight dissolved organic matter (Sherr 1988), also suggest that the large pools of sub- 
micron-sized particles which are present in seawater (Koike et al. 1990, Wells \& Goldberg 1991) may be accessible to grazing by flagellates. Clearly, current concepts of microbial processes in the sea must be altered to include grazing of viruses and virus-sized particles by flagellates. As well, our study reinforces the paradigm that phagotrophic nanoflagellates are key elements of nutrient cycles in marine ecosystems.

Acknowledgements. We appreciate the support and helpful comments by Drs Evelyn and Barry Sherr, the insightful discussions with Dr S. Strom and the technical assistance of A. M. Chan and F. Chen. We are grateful for the constructive comments of the reviewers. This research was supported by grants OCE-9018833 (NSF) and N00014-90-J-1280 (ONR) to C.A.S., OCE-8816428 (NSF) and OCE-8823091(NSF) to Evelyn and Barry Sherr, and a postdoctoral fellowship from the Spanish Ministry of Education and Science to J.M.G. Contribution no. 845 of the Marine Science Institute, The University of Texas at Austin.

\section{LITERATURE CITED}

Bergh, O., Borsheim, K. Y., Bratbak, G., Heldal, M. (1989). High abundance of viruses found in aquatic environments. Nature 340:467-468

Berry, S. A., Noton, B. G. (1976). Survival of bacteriophages in seawater. Wat. Res. 10: 323-327

Borsheim, Y., Bratbak, G., Heldal, H. (1990). Enumeration and biomass estimation of planktonic bacteria and viruses by transmission electron microscopy. Appl. environ. Microbiol. 56: 352-366

Bratbak, G., Heldal, M., Norland, S., Thingstad, T F. (1990). Viruses as partners in spring bloom microbial trophodynamics. Appl. environ. Microbiol. 56: 1400-1405

Dubowsky, N. (1974). Selectivity of ingestion and digestion in the chrysomonad flagellate Ochromonas malhamensis. J. Protozool. 21: 295-298

Fenchel, T (1980). Suspension feeding in ciliated protozod: functional response and particle size selection. Microb. Ecol. 6: 1-11

Fenchel, $T$ (1982). Ecology of heterotrophic microflagellates. II. Bioenergetics and growth. Mar. Ecol. Prog. Ser. 8: 225-231

González, J. M., Iriberri, J., Egea, L., Barcina, I. (1990a). Differential rates of digestion of bacteria by freshwater and marine phagotrophic protozoa. Appl. environ. Microbiol. 56: $1851-1857$

González, J. M., Sherr, E. B., Sherr, B. F. (1990b). Size-selective grazing on bacteria by natural assemblages of estuarine flagellates and ciliates. Appl. environ. Microbiol. 56: $583-589$

Hara, S., Terauchi, K, Koike, I. (1991). Abundance of viruses in marine waters: assessment by epifluorescence and transmission electron microscopy. Appl. environ. Microbiol. 57: 2731-2734

Heldal, M., Bratbak, G. (1991). Production and decay of viruses in aquatic environments. Mar. Ecol. Prog. Ser. 72: $205-212$

Hidaka, T. (1971). Isolation of marine bacteriophages from sea water. Bull. Jap. Soc. Scient. Fish. 37: 1199-1206

Hobbie, J. E., Daley, R. J., Jasper, S. (1977). Use of Nuclepore filters for counting bacteria by fluorescence microscopy. Appl. environ. Microbiol. 33: 1225-1228
Kapuscinski, R. B., Mitchell, R. (1980). Processes controlling virus inactivation in coastal waters. Wat. Res. 14: $363-371$

King, C. H., Shotts, E. B. Jr, Wooley, R. E., Porter, K. G. (1988). Survival of coliforms and bacterial pathogens within protozoa during chlorination. Appl, environ. Microbiol. 54: 3023-3033

Koike, I., Hara, S., Terauchi, K., Kogure, K. (1990). Role of sub-micrometer particles in the ocean. Nature 345: $242-244$

Malone, T. C., Ducklow, H. W. (1990). Microbial biomass in the coastal plume of Chesapeake Bay: phytoplanktonbacterioplankton relationships. Limnol. Oceanogr 35: $296-312$

Mathews, C. K., Kutter, E. M., Mosig, G., Berget, P. B. (eds.) (1.983). Bacteriophage T4. American Society for Microbiology, Washington, DC

Mayer, J A., Taylor, F. J. R. (1979). A virus which lyses the marine nanoflagellate Micromonas pusilla. Nature 281: 299-301

McManus, G. B., Okubo, A. (1991). On the use of surrogate food particles to measure protistan ingestion. Limnol. Oceanogr. 36: 613-617

Mitchell, G. C., Baker, J. H., Sleigh, H. A. (1988). Feeding of a freshwater flagellate, Bodo saltans, on diverse bacteria. J. Protozool. 35: 219-222

Moebus, K. (1980). A method for the detection of bacteriophages from ocean water Helgoländer Meeresunters. 34 : $1-14$

Muller, M., Rohlich, P., Toro, I. (1965). Studies on feeding and digestion in protozoa. VII. Ingestion of polystyrene latex particles and its early effect on acid phosphatase in Paramecium multinucleatum and Tetrahymena pyriformis. J. Protozool 12: $27-34$

Pace, M. L., Bailiff, M. D. (1987). Evaluation of a fluorescent microsphere technique for measuring grazing rates of phagotrophic microorganisms. Mar. Ecol. Prog. Ser. 40: $185-193$

Paul, J. H., Jiang, S. C., Rose, J. B. (1991). Concentration of viruses and dissolved DNA from aquatic environments by vortex flow filtration. Appl. environ. Microbiol. 57: 2197-2204

Porter, K. G., Feig, Y S. (1980). The use of DAPI for identifying and counting aquatic microflora. Limnol. Oceanogr. 25: $943-948$

Proctor, L. M., Fuhrman, J. A. (1990). Viral mortality of marıne bacteria and cyanobacteria. Nature 343:60-62

Rassoulzadegan, F., Sheldon, R. W. (1986). Predator-prey interactions of nanozooplankton and bacteria in an oligotrophic marine environment. Limnol. Oceanogr. 31. $1010-1021$

Rublee, P. A., Gallegos, C. L. (1989). Use of fluorescently labeled algae (FLA) to estimate microzooplankton grazing. Mar. Ecol. Prog. Ser. 51: 221-227

Sanders, R. W. Porter, K. G., Bennett, S. J., DeBiase, A. E. (1989). Seasonal patterns of bacterivory by flagellates, ciliates, rotifers, and cladocerans in a freshwater planktonic community. Limnol. Oceanogr. 34: 673-687

Sherr, B. F., Sherr, E. B., Berman, I (1983). Grazing, growth and ammonium excretion rates of a heterotrophic microflagellate fed with four species of bacteria. Appl. environ. Microbiol. 45: 1196-1201

Sherr, B. F., Sherr, E. B., Fallon, R. D. (1987). Use of monodispersed, fluorescently labelled bacteria to estimate in situ protozoan bacterivory. Appl. environ. Microbiol. 53: 958--965 
Sherr, B. F., Sherr, E. B., Rassoulzadegan, F. (1988). Rates of digestion of bacteria by marine phagotrophic protozoa: temperature dependence. Appl. environ. Microbiol. 54: $1091-1095$

Sherr, E. B. (1988). Direct use of high molecular weight polysaccharide by heterotrophic flagellates. Nature 335: $348-351$

Sherr, E. B., Rassoulzadegan, F., Sherr, B. F. (1989). Bacterivory by pelagic choreotrichous ciliates in coastal waters of the NW Mediterranean Sea. Mar. Ecol. Prog. Ser. 55: 235-240

Sherr, E. B., Sherr, B. F., McDaniel, J. (1991). Clearance rates of $<6 \mu \mathrm{m}$ fluorescently labeled algae (FLA) by estuarine protozoa: potential grazing impact of flagellates and ciliates. Mar. Ecol. Prog. Ser. 69: 81-92

Sokal, R. R., Rohlf, F. J. (1981). Biometry, 2nd edn. W. H. Freeman and Co., New York

Spencer, R. (1955). A marine bacteriophage. Nature 175 : 690

Stolze, H. J., Lui, N. S. T., Anderson, O. R., Roels, O. A. (1969). The influence of the mode of nutrition on the digestive system of Ochromonas malhamensis. I Cell Biol. 43:

This article was presented by D. A. Caron, Woods Hole, Massachusetts, USA
$396-409$

Suttle, C. A. (1993). Enumeration and isolation of viruses. In: Kemp, P. F., Sherr, B. F., Sherr, E. B., Cole, J. J. (eds.) Current methods in aquatic microbiology. Lewis Publ., Chelsea, MI (in press)

Suttle, C. A., Chan, A. M., Cottrell, M. T (1990). Infection of phytoplankton by viruses and reduction of primary productivity. Nature 347:467-469

Suttle, C. A., Chan, A. M., Cottrell, M. T (1991). Use of ultrafiltration to isolate viruses from seawater which are pathogens of marine phytoplankton. Appl. environ. Microbiol. 57: 721-726

Suttle, C. A., Chen, F. (1992). Mechanisms and rates of decay of marine viruses in seawater. Appl. environ. Microbiol. 58: $3721-3729$

Taylor, W. D., Berger, J. (1976). Growth responses of cohabiting ciliate protozoa to various prey bacteria. Can. J. Zool. 54: $1111-1114$

Wells, M. L., Goldberg, E. D. (1991). Occurrence of small colloids in seawater. Nature 353: 342-344

Wetzel, M. G., Korn, E. (1969). Phagocytosis of latex beads by Acanthamoeba castellanii (Neff). J. Cell Biol. 43: 90-104

Manuscript first received: May 29, 1992

Revised version accepted: December 2, 1992 